\title{
The Role of Distance Learning in the Development of the Digital Economy
}

\author{
Natalia A. Kanishcheva ${ }^{1 *[O R C I D}$ 0000-0002-2764-9921] \\ ${ }^{1}$ Yaroslav-the-Wise Novgorod State University, Veliky Novgorod, Russia \\ natalya.kanischeva@novsu.ru
}

\begin{abstract}
The article presents the results of the analysis of the problem of digitalization of the modern economy from the point of view of the possibilities of using the positive experience of introducing distance educational technologies into the higher education system. Distance learning technologies make it possible to expand the list of educational services, increase their availability and increase the percentage of highly qualified competitive professionals in the economic sector. The purpose of the study is to analyze and determine the possibility of developing the country's digital economy based on expanding the informatization of the higher education system through the use of distance learning technologies. Based on the analysis of the norms of current legislation, expert opinions, statistics and research data on the stated issues, the article discusses the advantages and disadvantages of e-learning, the introduction of distance learning technologies in the creation of an educational space for an effective digital economy in Russia. Currently, all kinds of changes are taking place around us, which affect all areas of life. These include the increased development of digital technologies, the evolution of the globalization process, which encourage all market participants to compete with each other, teach to quickly adapt to all kinds of changes, develop the participants' abilities for self-improvement. Also they increase the information space, which leads to the improvement of institutions and social structures, establishes a new type of economy in which information technology is the central element. This is all a manifestation of the digital economy. It is expected that in the future the results of this study will be used to solve theoretical and practical problems in the field of e-learning, as well as to develop methods for implementing distance learning, taking into account the specifics in Russia.
\end{abstract}

Keywords: distance learning technologies, informatization, education, digital economy

\section{INTRODUCTION}

Training standards for students, modern requirements for them already include the availability of some knowledge of the staff about various information technologies and skills to work with them. The evolution of employers' requirements and the expectations of society have a direct impact on the emergence of new areas responsible for the use of potential information space, which serves for the constant acquisition of knowledge and efficiency of labor activity. Therefore, thanks to the development of the digital economy, there is also an improvement in the field of the education system new standards and educational technologies are being formed and applied. Also, the new economy transforms the requirements for graduates in the areas of their study, and affects the change in the organization of the content and the process of education.

The use of digital technologies in the field of education raises its level and is the source of the emergence of new educational methods. Their introduction is necessary because they contribute to the solution of such existing problems that require a change in the attitude of each participant in this process - both the state and educational institutions. Examples of such problems are the commercialization of education, a decrease in its quality, unequal access to information technologies [1].

In 1985, in secondary schools in Russia, a general course on the basics of computer technology and informatics was included in the educational subjects, and several thousand of the first personal electronic computers were allocated to the education 
sector. It was an important decision of the government and gave rise to informatization in the field of education.

All kinds of efforts to digitalize the educational environment are being made by public authorities. They are actively discussing various issues at economic forums, which are devoted to major government programs. For example, these issues are the improvement of information and communication technologies and their implementation in the educational process. They also discuss such important points in the field of digitalization that have a direct impact on the education sector:

1) Additional education and retraining of specialists. Personnel who must have certain knowledge in the field of information technology play a special place in the digital economy. To obtain such specialists, it is necessary to open centers for mass retraining of personnel and advanced training. Such centers will allow employees of various organizations who do not have the opportunity to improve their qualifications and get acquainted with this or that technology on their own, easily master these competencies;

2) Improving the education infrastructure. It is necessary to form and introduce new approaches to the education process that can provide society with a high level of basic knowledge in the field of digitalization;

3) Transformation of digital infrastructure. The importance of these transformations is emphasized with the rapid pace of informatization of society, including the emergence of new technical means and the use of information networks. Therefore, now society is paying more and more attention to the use of distance educational technologies in the education process $[2,3]$.

Currently, the scientific community is actively discussing topics of current trends in higher education [4], the role of digital technologies in new models of education [5,6], solving problems caused by distance education in a pandemic $[7,8]$. Special attention is paid to the adaptation of the teaching staff to the extreme transition to digital services and remote platforms [2, 3, 9]. In general, it can be noted that the transition of universities to remote mode during a pandemic has become the most discussed topic at the moment, especially given the global pandemic in 2020-2021.

\section{MATERIALS AND METHODS}

The analysis involved data from sociological studies of the attitude of students and university teachers to distance learning, conducted by expert organizations during the lockdown period, analytical and informational materials of universities, bibliographic sources. The use of a systematic, analytical and integrated approach made it possible to study the foundations of the vision and structure of the digital economy, identify trends in the development of the market for higher education services based on the use of distance learning technologies.

The main elements on the application of which modern distance learning is based are:

- the methods that depend on the technical environment for information exchange;

- the medium that is used to transmit information - radio, mail, information and communication networks, television.

\section{RESULTS}

When using a distance-learning format such as information and communication technology, pedagogical goals are set such as:

1) Preparing students for life in the context of digitalization and their personal development. Using various information and communication technologies in teaching, students improve their communication skills, different types of thinking, aesthetic education. The digital economy undergoes various changes during its formation;

2) Creation and implementation of new technologies for the presentation of educational information. Such means as graphics, sound, color, all modern means of video technology allow to form during the educational process an environment similar to full-time education;

3) Improvement of information and methodological support in the work of the teacher, which will create opportunities for quick communication between the student and the teacher, establish cooperation between the teaching staff using computer communications;

4) Improving the system of control over the educational process. Digital technologies 
now make it possible during the work of students to effectively improve control over their activities and at the same time provide flexibility in managing the learning process;

5) Fulfillment of the social order of society. The emergence of a new type of economy sets new requirements for specialists, which changes the needs of employers in personnel. Therefore, the introduction of information and communication technologies into the education process forms information literate specialists;

6) Work on the motivation of students to the educational process.

Distance learning also solves problems that shape and improve the creative component of education, which is difficult to organize in full-time education. These tasks are:

1) accelerating the growth of the amount of available information about the scientific, cultural and historical achievements of mankind;

2) an increase in the heuristic component of the education process with the help of multimedia programs and interactive forms of education;

3) strengthening the active role of students in educational activities;

4) obtaining an opportunity for interaction between the student and his peers, teachers, consultation with highly qualified specialists.

One of the features of distance learning is that students go through the learning process and develop in the area they need for further work on their own. Awareness by students of the fact that the necessary skills and knowledge can be obtained, found and assimilated only when applying their own efforts, requires maximum responsibility and concentration from them in the learning process.

The advantages of the distance-learning format are:

1) the ability to receive education from anywhere in the world;

2) low cost of this type of education, in comparison with traditional education; this is due to a decrease in the cost of conducting classes due to the use of information technology, with the absence of rent, which is necessary when renting premises; also, each teacher can simultaneously conduct classes for several groups of students;

3) open access to the materials provided - after registration in the distance learning system, it becomes possible to use all the literature that the student needs;

4) the ability to connect to the course at a convenient time for the student;

5) the presence of a calm environment during training - mainly the certification of students takes place in the form of online tests;

6) the possibility of training people with disabilities.

However, the distance-learning format also has disadvantages:

1) the lack of the possibility of receiving fulltime consultations at the time necessary for the student;

2) lack of application of knowledge in practice for specialists in the field of medicine and other areas;

3) it is not always possible to verify student identification;

4) lack of "live" communication between the student and his fellow students;

5) weak motivation of the student - the student receives all the knowledge on his own, which needs to be approached responsibly;

6) not all students have the necessary amount of money to purchase a good computer with Internet access.

The disadvantages listed above can be minimized: if there is no possibility of a face-to-face consultation, then you can get it via Skype or by sending a message to the teacher; the absence of "live" relationships is convenient for some students, because it creates a more comfortable psychological environment for them and allows them to concentrate on their studies.

Currently, distance learning is developing, during which one can notice the main advantage of this educational form. For each student, his own, individually oriented learning process can be created, which increases the efficiency of mastering the course. It allows a student to acquire new knowledge and skills when using information and communication technologies, satisfies the need for educational services, taking into account finances, 
health, time limit. All this forms the success and competitiveness of students; therefore, it is necessary to provide students with access to data sources available in educational organizations, such as video and audio filming, computer knowledge, textbooks, databases, digital libraries, multimedia and others. Various e-learning environments or platforms are currently being used to make this a reality.

Now, distance educational platforms have a high level of development, which reduces the differences between distance and face-to-face education and is reflected in the maximum similarity of the educational communication process. In their work, it is important to use computer technologies, with the help of which exams and tests are carried out, as well as the organization of the educational process in the form of simulation.

Moodle is one of the renowned distance learning platforms. It is used to transfer and expand an existing learning environment into an online format.

This distance learning platform was developed in 1999 and continues to develop at the present time. The creator of Moodle is Australian professor Martin Dungiamos, programming language - PHP. This distance education platform is used in the learning process in more than one hundred and fifty countries of the world, because it has the ability to translate into 82 languages.

Moodle is an open-source system that strengthens communication between student and teacher and controls the educational process. The possibilities of this distance educational platform are the formation of your own course, income from its implementation, training using a mobile phone. Important qualities of the Moodle distance-learning platform are the ability to work with different information products, simplicity and facility of use. At the same time, this system has a high level of security, does not impose serious requirements on the browser and requires only one database. Moodle is also a virtual learning environment that can be used not only in education, but also in a business environment.

The Moodle education platform has formed various functions that are distance-learning tools and are now the standards for student education management systems such as a gradebook and calendar.

Training courses are the core-learning unit of Moodle. In the process of working with them, you can carry out:
1) checking the acquired knowledge and skills, as well as training using various tasks and tests; the completed work, students can send both in the form of text and in the form of files;

2) communication of the student with fellow students and the teacher, which can be carried out using chats and forums;

3) joint research and study assignments on a given topic, using mechanisms built into the remote system, such as seminars, wiki, forums and others;

4) transmission of acquired skills in electronic form using archives, lectures, files, web pages.

The advantages of the Moodle distance-learning platform are:

- ease of installation on different types of platforms;

- control over the safety of the course;

- simplicity of training organization;

- possibility of free installation and use of the system;

- availability of a description of all courses opened with the institution;

- the effectiveness of using the platform;

- the availability of various ways of obtaining the necessary consultations from the teacher for students;

- the ability to search for information on different courses $[9,10]$.

Currently, there are problems related to distance learning and affecting not only its implementation, but also the methodological and technical organization. The question arises of the need to form various requirements and standards that will be responsible for the quality of creation, introduction and support of distance learning courses. Special attention should be paid to the position of the teacher in the process of ensuring communication between all participants in the educational process, conducting a training course, creating a high-quality assessment system. Also, requirements have not been developed that will relate to the financial support of the distance learning format. This is necessary because the formation of a variety of materials for training courses and modules requires expenditures not only in time and in physical terms, but also economically. 
In this regard, it is necessary to form a new approach to the process of improving the educational environment of distance learning. It should be paid attention not only to the transfer of actual skills and knowledge, but also to the practical component of training, the development of professional competencies necessary for employers and society. It is very important to control the correspondence of the distance educational environment to the specifics of the perception of the digital generation. To do this, it is necessary to take part in the development of the digital economy with the help of training, to develop an innovative structure for a distancelearning course that will meet the key criteria for the development of global education.

In addition, for the effective development of the digital economy, it is necessary to provide support to universities in the process of informatization. Now it is being organized by the Government of the Russian Federation with the help of programs of methodological and financial support for the digitalization of universities. Thanks to these influences, subsidies are allocated for the development of the infrastructure of educational institutions, namely, for the optimization of reporting procedures, the use of information services and products, the modernization and purchase of hardware and software, the improvement of the qualifications of employees and the quality of information data that influence management decisions.

\section{DISCUSSION}

Distance learning technologies, as well as elearning, allow the entire society to use the knowledge embedded in them, speed up the process of obtaining feedback, intensify the educational process, spending a minimum of resources on this. Also, the effectiveness of training depends on a quality approach to the creation and use of educational materials. Therefore, introducing information technologies into the educational environment, universities need to take a serious approach to the formation of their educational products, project activities of students and ways of interacting with them. Then universities will be able to gain full access to all the benefits of the digital economy.

Concepts such as "distance learning technologies" and "e-learning" were introduced with the Federal Law "On Education in the Russian Federation" dated December 29, 2012 No. 273-FZ [11]. Thus, distance educational technologies are such technologies in the field of education, which are mainly introduced using information and telecommunication networks, and the interaction of teachers and students is realized indirectly. Also, the Ministry of Education and Science of the Russian Federation dated August 23, 2017 No. 816 approved the "Procedure for the application of e-learning, distance learning technologies by organizations carrying out educational activities in the implementation of educational programs" [12].

Distance learning is currently an information and educational organized system for the transfer of data, interaction protocols, information resources, organizational, methodological and hardware and software. It is focused on meeting the needs of society in the field of education. Therefore, in the 21 st century, this form of education can be an independent type of formal education.

\section{CONCLUSION}

Distance learning is an information and educational system that includes a set of methods and forms of interaction between students and teachers, information resources and tools, the availability of the necessary software and support that is needed to meet the needs of society in the field of education. Therefore, the use of distance learning, as one of the areas of information technology, has a direct impact on the evolution of the digital economy, which stimulates an increase in society's demand for new skills and knowledge.

Currently, distance learning is considered as an information and communication technology that opens up access to education for the whole society, regardless of the chosen course of study and place of residence. This technology makes it possible to organize classes for a large number of students, while using several highly qualified specialists.

Distance education forms new skills in working with information technologies, which is necessary within the framework of social order and digitalization of the economy. It has the potential to increase the level of self-education of students and motivation for learning, the development of creative abilities, which leads to an increase in its effectiveness. The implementation of distance learning in the educational process is necessary because this form contributes to an increase in the efficiency of mastering various areas and areas of knowledge and takes into account the individual qualities of both students and teachers.

The scientific novelty of the research is as follows: 
- the nature of training using distance educational technologies as a digital technology is indicated, which is necessary for mass introduction into the higher education system in the context of its constant modernization;

- analyzed the main factors in the development of learning using distance learning technologies;

- possible prospects and directions for the development of education using distance learning technologies in Russian universities are shown.

The scientific and practical significance of the study is determined with the possibility of using the results and conclusions obtained in the development of a strategy for the digital environment of a modern Russian university.

\section{REFERENCES}

[1] J.M. Barratt, F. Duran, "Does psychological capital and social support impact engagement and burnout in online distance learning students?", The Internet and Higher Education, 2021, vol. 51. DOI: 10.1016/j.iheduc.2021.100821

[2] Yu.A. Vinogradova, I.A. Donina, T.A. Semeikina, "Automated control systems in education", Bulletin of the Institute of Economics and Management, NovSU, 2018, vol. 2(27), pp. 19-22. (In Russ.).

[3] A.Yu. Nesterov, S.I. Babina, "Distance learning technologies for masters: application experience and students' opinions", Bulletin of the Institute of Economics and Management, NovSU, 2018, vol. 2(27), pp. 66-73. (In Russ.).

[4] N.A. Jogezai, F.A. Baloch, M. Jaffar, T. Shah, G.Kh. Khilji, S. Bashir, "Teachers' attitudes towards social media (SM) use in online learning amid the COVID-19 pandemic: the effects of SM use by teachers and religious scholars during physical distancing", Heliyon, 2021, vol. 7(4). DOI: 10.1016/j.heliyon.2021.e06781

[5] D. Peña, D. Lizcano, I. Martínez-Álvarez, "Learning through play: Gamification model in university-level distance learning", Entertainment Computing, 2021, vol. 39. DOI: 10.1016/j.entcom.2021.100430

[6] A. Qazi, J. Qazi, Kh. Naseer, M. Zeeshan, Sh. Qazi, O. Abayomi-Alli, I.S. Ahmad,
M. Darwich, B.A. Talpur, G. Hardaker, U. Naseem, Sh. Yang, Kh. Haruna, "Adaption of distance learning to continue the academic year amid COVID-19 lockdown", Children and Youth Services Review, 2021, vol. 126. DOI: 10.1016/j.childyouth.2021.106038

[7] G.L. Tortorella, G. Narayanamurthy, V. Sunder M., P.A. Cauchick-Miguel, “Operations Management teaching practices and information technologies adoption in emerging economies during COVID-19 outbreak", Technological Forecasting and Social Change, 2021, vol. 171(3). DOI: 10.1016/j.techfore.2021.120996

[8] S. Severino, F. Aiello, M. Cascio, L. Ficarra, R. Messina, "Distance education: the role of self-efficacy and locus of control in lifelong learning", Procedia - Social and Behavioral Sciences, 2011, vol. 28, pp. 705-717. DOI: 10.1016/j.sbspro.2011.11.132

[9] C. Medio, C. Limongelli, F. Sciarrone, M. Temperini, "MoodleREC: A recommendation system for creating courses using the moodle e-learning platform", Computers in Human Behavior, 2020, vol. 104. DOI: 10.1016/j.chb.2019.106168

[10]P. Ifinedo, J. Pyke, A. Anwar, "Business undergraduates' perceived use outcomes of Moodle in a blended learning environment: The roles of usability factors and external support", Telematics and Informatics, 2018, vol. 35(1), pp. 93-102. DOI: 10.1016/j.tele.2017.10.001

[11] Government of the Russian Federation, Federal Law "On Education in the Russian Federation" [Ob obrazovanii v Rossiyskoy Federatsii] (December 29, 2012 No. 273-FZ). Moscow, 2012. (In Russ.). Retrieved from https://base.garant.ru/77706811

[12] Ministry of Education and Science of the Russian Federation, Order "On approval of the Procedure for the application of e-learning, distance learning technologies by organizations carrying out educational activities in the implementation of educational programs" $[\mathrm{Ob}$ utverzhdenii Poryadka primeneniya organizatsiyami, osushchestvlyayushchimi obrazovatel'nuyu deyatel'nost', elektronnogo obucheniya, distantsionnykh obrazovatel'nykh tekhnologiy pri realizatsii obrazovatel'nykh programm"] (August 23, 2017 No. 816). Moscow, 2017. (In Russ.). Retrieved from https://base.garant.ru/71770012 